\title{
THE KEY THEORETICAL AND PRACTICAL ASPECTS OF THE STATE FAILURES IN THE CONTEMPORARY ECONOMY
}

\author{
Dragan Petrovic* \\ Faculty of Economics, University of Nis, Nis, Serbia
}

\begin{abstract}
The subject of this paper is to analyze the evolution of approaches to the problem of the "state failure". This phenomenon arose from the concept of "market failures", which in economic theory can be seen in the context of searching for new strategies of the political and economic mechanisms of resource allocation. In this regard, special attention will be focused on the identification of the components of the institutional impact on the efficiency of economic processes, which first involves a general review of the role of the state in the economy. A multidisciplinary approach to the study of such a complex issue requires, among other things, that all information problems in the analysis of the economic functions of the public sector be taken into consideration, that the possibilities of financing public policy measures be appreciated, that the role and influence of the political process and the rent-oriented behavior of public officials be adequately evaluated, and ultimately that an attempt to identify the negative external effects caused by the absence, but also by the presence, of the state coordination in the economy be made.
\end{abstract}

Keywords: state failures, the theory of public choice, the mechanism of collective decision making, informational problems

JEL Classification: D72, D73, D74, H41

\section{INTRODUCTION}

The demands for limiting the state activity in the economic sphere existed even in the period when the market economy was appearing and was being founded. It is well-known that the representatives of physiocracy agreed that the task of the state was to provide conditions for the functioning of the free and

\footnotetext{
* Correspondence to: D. Petrovic, Faculty of Economics, University of Nis, Trg kralja Aleksandra 11, 18000 Nis, Serbia; e-mail: dragan.petrovic@eknfak.ni.ac.rs
}

unlimited competition. In this sense, the importance of the classical school is even more evident, having in mind the fact that the opinion that it offered certain essential guidelines about the functions of the state in the market economy is prevailing in economic theory. A. Marshall has introduced the notion of 'external effects', with the intention to point out the extent to which they can limit the sphere of the market regulation. A. Pigou thinks that the existence of such effects inhibits normal economic processes, lessening the possibilities of the national income growth (Pigou, 1932, 173). The above conclusions about the fact that 
the market cannot lead to the optimal allocation of resources by its free impact served as the basis for formulating the well-known notion of market failures.

The existence of market failures is the key argument for intensifying the state intervention, or activating the so-called solutions not related to the market. Empirically speaking, the real expansion of the state's economic functions was primarily conditioned by the strong economic depression and turbulent war incidents. However, after the end of the World War II, the tendency of the growing role of the state in the economy continued to exist.

The representatives of the liberal economic thought firmly opposed the strong and improper state intervention in the economic sphere of social life. They pointed out that there were negative consequences to the state activities, which provoked some economists to formulate the alternative category of the so-called 'state failures', parallel to the category known as market failures. Having all this in mind, the object of the research of this work is directed towards examining the potential factors of the relative efficiency of the market and the state mechanisms of the allocation of resources in situations when the market cannot lead to optimal economic and social results by its own free impact. That is the reason why the starting hypothesis in this work is related to the fact that the state policy directed towards the correction of market failures can, as a matter of fact, cause an even worse state in comparison to a state should such a policy fail to exist. This means that failures of the market do not have to represent an a priori argument for the so-called solutions not related to the market.

The basis of the approach to this research will be the theoretical, structural analysis of the object of the research on the basis of elaborating available secondary sources. This means that the stated hypothesis will be tested by an empirical research conducted by different authors who were analyzing this problem. After that, the combination of a 'historically deductive' method, starting from obvious facts, and a hypothetically deductive method, having presumptions as its basis, will be applied in order to come to the general conclusions related to the necessity of the interfering of the state in a case of market 'breakdowns'. Special attention should be paid to the comparative analysis of both variants of the using and directing of resources, which should finally lead to a valid answer about the question whether and when it is necessary to substitute the market when it does not lead to the Pareto efficiency.

\section{DETERMINING THE NOTIONS OF THE MARKET AND STATE FAILURES}

The expansion of the state and centralized regulation were observed by F. Hayek (2000) as a process threatening citizens' rights and limiting the freedom of market participants. His rigid attitude against state interventionism is based on the presumption that the market is a more superior coordination mechanism than unreliable state planning. The logic of this approach is that individuals are more aware of their preferences, expenses and relative prices, while state planners must know much more if they want to substitute a state mechanism. While in the system of prices every individual must only understand his own situation, a planner has to respect everybody's interests. Social life and its economic sphere in particular are rather complex and from this we can conclude that planners base their strategies on limited, insufficient and fragmentary knowledge and information. That is why it can easily happen that activities carried out by 'well-intentioned' governments result in unwanted consequences and a decrease in social welfare.

Apart from informational and cognitive problems related to the creation and implementation of state measures in the economy, it is necessary that the expenses of state regulation should be taken into account. As opposed to the immediate results of interfering with the state order, usually very obvious, many side-effects still remain unfamiliar. As F. Hayek said, "it hasn't been made possible for us to know all the expenses caused by the state intervention in the sphere of economy" (Хайек, 2006, 75).

Recognizing the negative consequences of the state activity caused the forming of the category of the socalled state failures in economic theory. C. Wolf (1979) was the first to propose the conception of failures 
unrelated to the market and later the term "state failures" was more commonly used. The phenomenon of state failures implies that whenever legislators and members of a government reach decisions on making interventions caused by certain market failures, they often make even bigger mistakes (Gunning, 2002). The representatives of the theory of social choice also wrote about different causes and types of state failures. (Tullock et al, 2002).

As time passed, the problem of state failures started attracting greater attention of economists, even to such an extent that some authors classified the shortcomings of state regulations into the same group as market failures. There is an opinion that the models of state failures are completely analogous to the theory of state failures according to their goals and methods of research. Moreover, the analytic achievements of those models are largely compatible as well as their weak sides are (Bozeman, 2002, 157). It is indicative that many economists who used to propose the thesis of the necessity of state interventionism in the economy related to market failures are now the spokespersons of a completely different attitude: unfavorable consequences related to state failures can be more serious than those in the case of market failures. (Радыгин \& Энтов, 2012, 6).

The existence of state failures again makes topical the conception of state failures, which is why, to a certain extent, their comparison is getting the character of an 'eternal question', leaving open the discussion on whether the state should always interfere when there are some market failures. The examination refers even more to the question of which theoretical presumptions should be in the basis of the concept of the state failures.

Being actually faced with market failures influenced the occurrence of the theoretical models which the state used to provide the market balance with the help of non-market methods. The positive attitude towards the need for the state to interfere in the case of market failures was more or less explicitly held by many representatives of the leading economic theory, starting from the so-called marginalism revolution. The accumulated experience related to numerous successes made by the state made this question topical not at the level of substituting the market in a case when it does not lead to the Pareto efficiency but rather at the level of comparing the two variants of using and directing resources with each other.

Methodologically speaking, it is necessary that the theoretical model presupposing that the state can maximize social welfare in the case of the occurrence of market failures should be compared with the theoretical model of free economy, based on maximizing an individual gain and profit (Tullock, 1978). On the one hand, market forces cannot provide an adequate supply of certain goods. On the other, the functioning of decentralized market mechanisms in principle calls for a smaller quantity of necessary pieces of information needed for reaching decisions related to the market. In relation to this, it is necessary that the following questions be answered: Which social welfare maximizing mechanisms is it possible to use? and Is it realistic to control the impact of those mechanisms?

\section{INFORMATIONAL PROBLEMS AND CREATING NON-MARKET SOLUTIONS}

In the process of analyzing the public sector, the key question is related to the problem of gathering and processing information necessary for choosing the way in which the state will react in a concrete case. In this case, the situation is in principle different in comparison to the usual practice in the sphere of private enterprises. By analyzing the functioning of market mechanisms, modern economic theory points to the fact that, in the process of the market mechanism, there are certain realistic presumptions which individual economic participants base their business on. However, when state-owned companies produce goods that cannot be provided by the market, then, as a rule, information about preferences of market participants is incomplete or missing. The existing methods of expressing individual 'non-market' preferences do not allow the creating of mechanisms capable of contributing to the strengthening of the allocation efficiency. 
In a situation when participants of economic processes would honorably speak about their preferences, it would provide information necessary for making an improvement, according to Pareto. However, any doubt that the offered information would be used for making an improvement according to Pareto would influence people to, maybe, offer incorrect and insufficiently reliable information (Tideman, 1997, 237). If, for example, we conducted a survey of a group of potential users and their preferences, and simultaneously another one of the limits up to which they are ready to pay, then we would probably find out that such individuals have a greater interest to present that their borderline utility from spending the given quantity of goods is much smaller, in order to lessen the sum they pay for using it. Contrary to this, however, if they did not pay, they would exaggerate their utility from the public goods.

Road construction is the example taken by Mankju $(2004,229)$ in order to point out the existence of serious problems the state is being faced with while determining the utility and expenses related to securing public goods. According to him, it is neither reliable nor simple to ask people how much they think a new highway would cost. Potential users of the highway would be inclined to exaggerate the benefit they would have from having the highway built. Those who would suffer damage from having the road built would exaggerate the expenses they would have in order to prevent it from being built. Therefore, it turns out that we all want to have safer roads if we do not have to bear the costs of their building (Kitanović et al, 2011, 53). When the Republic of Serbia (RS) is concerned, it is evident that the majority of the citizens of RS support the existence of the public service but are not supportive of paying their television subscription.

As a rule, the previously mentioned problems result in numerous difficulties in the process of gathering and adequately using information about market participants' preferences as well as during the formation of the basis for the state activity and the procedure of public choice. Whether the offered quantity of public goods is close to the socially optimal quantity or not depends on how precisely individual or social preferences for such public goods are identified.
The provision of public goods with the help of the public sector is justified by the reasons of providing the socially optimal quantity of these goods. However, problems making the market inefficient and representing an argument in favor of non-market solutions appear during the provision of these goods in the public sector. We primarily have in mind the almost unsolvable problems of information gathering. Without a correct judgement of preferences, neither the decentralized market nor the public sector can provide the Pareto-optimal quantity of public goods.

When it comes to public goods, the correct judgement of preferences is primarily concerned with the questions whether it is possible to define integral social preferences from different individual preferences. The neo-classic based the solution of this problem on paying the maximal respect to the so-called utilitarian tradition. Essentially, it means making an attempt to derive consistent social preferences on the basis of individual preferences, aggregating the total level of utility of all people included. Simultaneously, this means that there is no comparing of individual preferences, so the economy of 'welfare' is only based on the one basic criterion of improvement - the Pareto criterion. However, many attitudes about the division of social utility are not included, nor are all the other factors that have no influence on the creation of this utility, which is why this explanation has been exposed to severe criticism (Sen, 2004, 343).

K. Arrow and J. Buchanan have made a great contribution to the analysis of the process of collective decision making and the system of social preferences. At first, K. Arrow expressed a doubt in the possibility of forming aggregate value judgements about social welfare, wondering whether there is a valid procedure of social decision making that, to a reasonable extent, shows respect for individual values and preferences or not?

In his attempt to answer the question, K. Arrow states that, in order to define integral social preferences from various individual preferences, conditions have not been created, especially those related to the desirable characteristics of the voting system. Characteristics such as transitivity, independence from irrelevant alternatives and the non-existence of the dictator 
cannot satisfy any voting system, which the literature refers to as Arrow's 'theorem of impossibility'; there have also been numerous subsequent attempts to verify these statements and proofs (Geanakoplos, 2005, 212).

\section{THE PROBLEM OF FINANCING PUBLIC GOODS}

While researching the mechanism of the functioning of the public sector, an answer to the question related to the possibility of the reliable financing of state measures connected to the provision of public goods is given a special role. The classical approach is primarily dedicated to the problem of 'fair taxation'. It is assumed that the sum of taxes paid by every participant in order to provide public goods should be in proportion with individual preferences related to these goods. Such an approach transfers the usual principles of market relations among private individuals to the sphere of state finances, while taxes are treated as individual or personalized prices for the services provided by the state or state-owned companies. However, this is when individuals (or companies) insufficiently benefiting from the functioning of certain public goods or disagreeing with the obligations of their financing can abandon paying certain taxes.

Therefore, it turns out that there is a contradiction in the nature of public goods (Petak, 2001, 18). The characteristic of inexhaustibility or mutual supply motivates all members of a community to cooperate in providing public goods. Whatever goods may be in question, all members of the community will benefit from contributing to the creation of such goods. Simultaneously, the non-existence of efficient mechanisms for exclusion influences the occurrence of 'free users' or those using public goods but not wanting to participate in their funding. That is why the provision of public goods is connected with a fundamental principle - the providing of the whole amount of the state budget is created in an involuntary way, tax-payers in democratic countries want to feel the immediate connection between the part of their income they give for taxes and the benefits they get on the basis of spending on public goods. So far, however, there have been serious discords between tax payers' preferences and the budget policy of the state. It can be analyzed in such a way that the compensation for using public goods is not directly related to the scope of its use. A decision on the amount of supplies of public goods is reached in the political sphere of social life instead of on the market. That is why, in the majority of democratic countries, their citizens cannot determine the kind of public goods they want, or their quantity or quality. The nature of public goods is such that an individual has little choice regarding their spending, or they have to accept the given quantity and quality of such public goods that they are being offered.

In the basis of the conflict between individual preferences and decisions on public goods brought by the state, there lies the problem of a mutual fund. As a matter of fact, representatives of executive authorities can use the mutual fund in a manner they deem correct, or ignoring the interests of the users of goods that are being financed from that mutual fund. That is why practical solutions in the domain of public goods can be said to, to a considerable extent, be dependent of the political order of a country.

\section{COORDINATION, CONFLICTS AND THE ROLE OF THE RENTING BEHAVIOUR}

According to the concept of social welfare and other analogue theoretical models, the state acts as a unified political institute that has mastered the right of monopoly over using coercion on a certain territory (Weber, 1958/1921, 78). If we keep in mind the economic sphere of social life, we can first mention the neoclassical definition according to which the 'economy is a science of human behavior as a relationship between aims and limited resources that have the possibility of alternative use' (Robbins, 1962, 16). The understanding of the fact that the economy analyses the optimal usage of limited resources implicitly presumes that once we have found an optimal solution, or an optimal economic policy, it will be applied (Drazen, 2000). This means that the key challenge is to determine optimal measures, rather than have such measures realized, which is why the problem of choice of a suitable economic policy is reduced to a technical problem. 
In practice, however, this thesis about the existence of an ideal state whose representatives solely strive to satisfy the interests of the citizens is often denied. First, we have to conclude that the functioning of the state is a highly complex hierarchical system. The impact of different, often rather fragmentary, levels of power (legislative, executive, judicial) is as a rule not coordinated, while in some cases there is no direct contradiction in the process of fulfilling their aims and tasks.

In addition to the objective difficulties accompanying the process of organizing the reaching and execution of the state-brought decisions, there are some other reasons why it is desirable that the state should not intervene. As a matter of fact, there is a doubt that the applied macroeconomic policy would not be suitable for optimal solutions, not because of technical or informational limitations but because of political obstacles. Political obstacles are related to the conflict between individual interests in the society, as well as a necessity to make unique social choice in the conditions where contradictory interests are present. Firstly, sharp contradictions between the executive and the legislative authorities can result in the absence of a unified strategy and, in that sense, in the absence of an optimal economic development. An adequate 'swaying' of the economic system is intensified by an influence of political cycles and a populist policy, which necessarily brings additional expenses and lowers the level of social welfare.

In conditions allowing for a possibility for conducting legal market activities, a conflict of regional and other individual interests could be regulated by reaching a commercial agreement and an adequate system of compensation and payment according to the system of the so-called 'Kouz's theorem'. As a matter of fact, as opposed to the state that can face a 'breakdown', in R. Kouz's opinion (Koy3, 1993, 142) the market is capable of turning every initial allocation of resources into Pareto's optimum. According to this opinion, the interested parties, with certain problems and conflicts of interests, can find a solution by negotiating without the intervention of the state. The conditions for this are clearly defined rights of property and low transactional expenses.
Therefore, the essence of Kouz's theorem lies in the fact that it accentuates the connection between private property and satisfying general social interests, pointing out arguments against the interfering of the state in solving problems between economic subjects. That could be explained by the fact that a successful realization of rights of property, in fact, initiates the individual awareness of the total social expenses when bringing decisions on whether to undertake economic activities or not (Alchian \& Demsetz, 1973, 24).

In the political sphere, however, there is no relying on the functioning of Kouz's market mechanisms that provide a movement or progress towards an optimal solution (Acemogly, 2003). With the help of the standard models of the theory of games, it is not difficult to show that balance in Nesh's sense in certain situations presupposes the determining of a non-optimal (proportionally big) number of activities and relatively long terms of the introduction and functioning of the same. In a large number of cases, the state confirms the stated tendency, broadening its activity out of the optimal boundaries of an impact (Радыгин \& Энтов, 2012, 12).

That is the reason why the research of the influence of political attitudes on economic outcomes and results has been offered in the boundaries of the modern political economy, which also means there is a certain interest related to the occurrence of inadequate and 'distorted' decisions of the legislative and the executive authorities. In the process of reaching such decisions, there are often activities directed towards obtaining certain conveniences, or gaining a profit outside the market and market activities, which in the literature is known as seeking for rent (rent-seeking). The circumstances for obtaining a rent appear due to the legislative activity of the state and its bodies, the market limitations, subvention, regulation, allocation etc.

Rent-seeking is a typical mechanism for imposing particular interests as social (Prokopijević, 2000, 324), and as such, it is fairly present in the domain of reaching and taking protection measures in foreign trade. As a matter of fact, there is a research showing the obvious inertness and stability of renting incomes related to the conducting of protectionist measures 
of the trading policy (Krueger, 1990). Thanks to this situation, the competition on the domestic market is reduced, the variety of supply is also reduced, as well as the purchase power of consumers, who bear the burden of high prices in the long term. Additionally, protectionism has a negative influence on the redistribution of incomes since it leads to the redistribution of the consumer's incomes and unprotected branches towards protected branches of economy.

The costs of rent-seeking can be rather high, and they depend on numerous factors such as the degree of the regulation of the economy, legal security, the number and structure of limitations and prohibitions, the customs, the level of prosperity etc. Some models of the theory of games analyzing the influence of the renting-oriented behavior while reaching decisions in the process of different election systems bring the level of rents in relation to the number of political participants taking part in elections. In accordance with this, the size of balancing rents essentially depends on the intensity of competition among different social groups in the political arena: by reducing the number of candidates participating in elections and with certain presumptions, the growth of the balancing rent appropriated by participants in the political life is inevitable (Myerson, 1993). The level of rents and the problems of the rentingoriented behavior are connected with a choice between centralized and decentralized mechanisms of regulation. By reducing the inclination towards a risk of participants in an economic process, the centralized allocation of resources and the state apparatus ask for more significant stimuli for government officials and a higher political rent, which further generates additional expenses and leads to the reduction of the welfare of the state.

\section{THE ROLE OF THE POLITICAL PROCESS}

The essential importance for the appearance of state failures can be ascribed to the marks of political processes, primarily those related to the way of reaching and controlling the government's decisions. First, we should conclude that the world of political solutions is 'ruled' by a separate logic, based on the explanation of the suggested measures, and this fact can deviate from the strict economic pinion on the influence of these on the efficiency of the functioning of the economy and the growth of social welfare.

Analyzing the limits of state regulations, it is not hard to observe that in many countries there are rather firm institutional relations between the government and less efficient corporations, primarily those owned by the state. The empirical data show that, as a rule, these companies are very interested in different forms of centralized support. On the other hand, an influential policy and highly-rated state official workers may, in certain situations, need an active support from 'their own' companies.

Change in general conditions of economic growth can lessen the need for centralized regulation. However, the bureaucracy apparatus that was influential in that system was interested in keeping and broadening its jurisdictions and functions. In this sense, on the one hand, the additional insurance of jobs is ensured, while on the other, self-importance is shown. When a bureaucrat asks for an increase in the number of employees, justified by the employees overworking themselves, by the improvement and enlargement of the scope of services, then it is hard to check the validity of such statements. For some jobs, there are no exact indicators, and for the other ones, there are such indicators, so the evaluation of the work and efficiency of a bureaucrat is rather based on an intuitive impression of the superiors (Kitanović et al, 2011, 75). The growth of bureaucracy is therefore an endogenous process according to which the bureaucratic apparatus, administrative institutions and state-owned companies are subordinate to the laws of the functioning of an organization. Certain aims are inherent to the system as well as the creation of additional strategies and their self-preservation.

The process of bringing laws and other decisions by the state is subject to a complex and rather dissected procedure of decision making. In case certain political powers and state organs fail to provide their support to creating certain laws, it is highly probable that there will be a certain middle solution in the direction of the improvement of the proposed legal 
solutions. The scope of influence can be reduced through such political coordination and shaping of those mechanisms that should clear the way towards reaching optimal changes according to Pareto.

When the issue of reaching political decisions in the theoretical models of modern political economy are concerned, there is a difference between politicians and bureaucrats. Essentially, the concrete impact of both can reach a certain level of independence concerning the official announcement of the priority of the state policy. In relation to this, it is necessary that we raise the question of the optimal determining of the state functions between politicians and bureaucrats as well as the appropriate criteria of optimality (Alesina \& Tabellini, 2007). Although bureaucrats are often perceived as gears in the machine, or reliable and efficient executors of the delegated duties, acting within a certain hierarchy and in compliance with clearly defined rules, they de facto significantly influence the political process. The reason for this is that, having once come to power, parties cannot directly conduct their policy, but bureaucracy has a jurisdiction for executing political decisions. Therefore, it turns out that a greater part of administrative work is left to official workers of the state, which is why they have a significant freedom in choosing the way which they execute political decisions in. Because of that, the partly modified scheme of the so-called principalagent problem can be said to also be applicable in the analysis of the functioning of the public sector. The structure of the proposed model would be made of an active individual - a bureaucrat, on one hand, and an abstract political institute at a higher level controlling them - the state, on the other (Banerjee, 1997). In such a system, there is a certain asymmetric distribution of information - bureaucrats are more acquainted with the problem than their superiors are. This means they can manipulate with how much, when and in which conditions they want to offer their knowledge to their superiors. Since politicians reach decisions on the basis of available data, bureaucrats can significantly influence the content of such reached decisions. They can control the flow of information and only offer the information in the interest of bureaucracy.

Unfortunately, the problem does not only lie in the asymmetric impact of official workers of the state. A significant role can also be ascribed to the impact of various social levels and groups, where certain groups can significantly influence the carrying out of the state policy. As a matter of fact, an essential role in the choice of the macroeconomic strategy of the state can be held by political reasons of a purely tactical character directed towards the 'maximizing of popularity'. The above-mentioned connection can result in a political cycle based on the presumption that the political party holding the power can cause a decrease in the level of unemployment in order to improve its chances for re-elections (Nordhaus, 1975). The process of changes at the level of employment is conducted by creators of the economic policy through a monetary and fiscal expansion before elections, while inflation will start to grow immediately after the elections (Praščević, 1999).

It is not difficult to conclude that social-political 'manoeuvres' aimed at reaching tactical goals do, in many cases, not only cause economic instability but can also have catastrophic consequences in the long term. The extreme simplification of political arguments further reduces the circle of possible opportunities for the consistent realization of a long term economic strategy. In these circumstances, the appropriate and explainable measures of the government's policy often lose their systematic character and foundation, becoming irrelevant from the standpoint of an economic logic.

As part of economic research during the 1980s, special attention was paid to essential contradictions and presumptions, which the theory of the functioning of the public sector was based on. On the one hand, in its description of the scope of the influence of market participants, the generally accepted theory starts from the standard function of the aim characteristic for the interests of the so-called 'economic man'. On the other, as participants in non-market operations are usually the subjects without any private interests in the reestablishment of these works, although there is no doubt in their professional capabilities.

Analyzing a complex set of motives used by representatives of power and official workers of the state leads to the conclusion that the development of strategies and the realization of the functions of the state are not always performed by these subjects in a conscientious and professional way. Since they can 
have their own interests in doing this work, the starting hypothesis is that bureaucrats and participants in the private sector act rationally, governed by their own interests (Niskanen, 1971). In this way, the economy of public choice becomes affirmed as a relatively new science, consisting of the two sciences - political theory and economics. It researches the purpose of applying an economic analysis in political decision-making (Buchanan \& Tullock, 1962, 7), striving to apply the methodological presumptions of the economic science to the process of reaching collective decisions, where the basic participants are political parties, voters, politicians, groups of interest and bureaucracy.

The renting-oriented behavior of political participants and official workers intensifies with the broadening of the jurisdiction of the state, when one means of competitiveness among private companies becomes a relation with the structures of the government. That is how the relations built between the state and the economic subjects are, as a rule, more limiting to the efficiency of the functioning of the organs of the state in the economic area. The results of the state bureaucracy are, among other things, brought into relation with the existence of different priorities of the economic activity in the state and the private sector. While a private owner is immediately interested in the economy of resources, the leaders in the state organs and companies strive not to allow some part of their budget means to remain unspent, or used for a different purpose.

The importance of the expenses of the delegation of jurisdiction, which also includes the so-called X-inefficiency (Vining \& Weimer, 1990), also grows as the scope of the jurisdictions and operations of the state or the scope of production in the public sector does. The inefficiency caused by the weakening of competitive mechanisms and the market discipline is the one to lead to a situation when almost all company expenses obtain a justified character in the direction of the optimization of the aim functions.

The prominent absence of a typical official worker's inclination towards a risk belongs to the important factors influencing the reduction of the work efficiency of the organs of the state. Since criteria for the evaluation of the consequences of nontrivial solutions can fairly be broadened, a possibility of unfavorable outcomes becomes essentially bigger. That suppresses useful initiatives by official workers and causes previous evaluations, reconciling and starting numerous securing procedures, which in principle leads to the prolongation of reaching decisions, limiting their impact.

The monopolist position of many bodies of the government and organs of the state and the absence of the market competition does not mean there are no competitive relations among these separate entities, formally completely divided. By striving to broaden their activity and influence in the conditions of limited budget resources, many state organs and their leaders strive to 'limit' their plans or to 'swallow' other bodies of the state and organizations. In this way, internal conflicts limit the possibilities of a coordinated impact of the state, reducing the efficiency and outcome of the state policy. Having in mind the special role of the state in modern economy, it is possible to assume that corruption, the bureaucratic routine and contradictions inside the apparatus of the executive authorities are becoming a problem not much smaller than the absence of coordination is, which many market failures have been connected with (Радыгин \& Энтов, 2012, 19).

\section{THE REGULATORY FUNCTION OF THE STATE}

Valid determining can also be analyzed according to the state's failures in the context of necessary influences in the direction of preventing the creation of market failures, and in that sense, later breakdowns of the state in its striving to repair or lessen the consequences of these shortcomings can also be prevented. Since according to the institutionalized understanding, failures of the market are the consequence of the inefficient institutional order, it is necessary that the state should activate itself in the area of making and executing laws in the field of property protection, the application of contracts and guaranteeing foreign investors' rights. Therefore, it turns out that the more imperfect the market is, the more important the role of the state and its institutions is, and vice versa. (Lekovic, 2012, 70). 
The above-mentioned approach does not call for an active intervention of the state in the Keynesian or Marxist sense, with the intention of the state to take over some authority over the market. Therefore, we do not start with the market and the state as an antipode but rather with a little paradoxical statement that, for private property institutes and the market to normally function and be protected, it is necessary that there be a mechanism based on the principles of centralized and collective property. Understanding relations between the market and the state in such a manner was not unknown to F. A. Hayek, either, when he stated that 'to the extent to which we want to use the services of the market powers - and we definitely have to use them if we want to keep our life standard - the rational economic policy has to be limited to creating the conditions in which the market could function better' (Hayek, 2001, 137). Therefore, it turns out that it is the best to profile the complementary relation between the state and the market, where it is desirable that activities carried out by the state in the field of establishing an institutionalized frame as well as a significant reduction of direct, personal interference in the courses of the economy should be intensified. From the standpoint of the psychological science, it is a phenomenon of the self-identification of the state as a regulator which has obviously got the character of a chronic problem in many countries (Радыгин \& Энтов, 2012, 20). Such an unfavorable scenario has to a great extent been connected to the inadequacy of stabilizing mechanisms and political institutes that would provide balance between the goals of the state and the goals of its agents. What is even more problematic in this sense is that the state is expected to leave the position of the general manager and redistributors in the economy and to primarily become the creator of the institute of the market economy and the keeper of the 'rules of the game' (Sekulovic, 2004, 114).

\section{THE RELEVANCE OF THE EMPIRICAL RESEARCH OF STATE FAILURES}

There is a widely spread opinion among the economists that state failures are literally grown together with the organization of the state and its order and as such make an inseparable, integral part of the functioning of the state order. The impression is that the broadest classes of the population have an attitude that the expenditures of state intervention are too high and that failures of the market are not being corrected by the state in a successful way and free of charge. Although the adequacy of citizens' understanding, analyzing and making conclusions about inefficient actions of the state should not be denied and depreciated, representatives of social sciences have strived to confirm the thesis of the existence of state failures in their empirical research. In this sense, it is desirable that the contribution of several theoretical directions, some of which have influenced political sciences, while others are closer to the economic science, should be highlighted. For example, the positivist school of Rochester, whose founder was W. Riker, researched choices, parties' strategies, making coalitions, bureaucracy behavior etc. (Rowley, 2008, 3-29). An important contribution to the empirical verification related to the existence of trade on the political market is connected to G. J. Stigler (Stigler, 1971, 3-21), a representative of the Chicago school. Inside the Virginia school, there were a number of studies against state intervention in the economy. Guided by J. Buchanan and G. Tullock, they pointed out the facts that proved the absence of the altruistic motives of participants on the political market, such as executive power, bureaucracy, groups of interest, legislative bodies, etc. In their critiques of the 'political markets' and failures of the political impact they warn us of the problem of trading with votes. It is hard to ignore the facts about the voting of certain individuals against their preferences, or voting for what they do not agree with, if they receive support for their proposition. (Buchanan \& Tullock, 1962, 4346).

Having in mind the fact that searching for a rent is one of the fundamental concepts pointing out state failures, empirical researches demonstrating that searching for a rent is a characteristic of any political system are indicative (Hindmoor, 2006, 161). It is almost impossible to find societies in which there is not a certain kind of looking for a rent. According to a research by R. Posner, during the 1970s, the expenses of looking for a rent in the USA accounted for $3 \%$ of the 
American national income at that time. It is logically to suppose that these expenses were higher in the states where corruption was more present, usually ranging between $5 \%$ and $40 \%$ of the national income (Posner, 1975, 807-827).

The existence of state failures can, among other things, be related to the problem of a collective impact. $\mathrm{M}$. Olson's idea, according to which any collective impact is connected to the problem of the 'independent user', is in practice followed by numerous obstacles connected with the motivating of members of social groups to more actively participate in reaching the aims of these groups. That is exactly the thing characteristic for the process of securing public goods and the activities of trade unions (Olson, 1965, 12, 66).

\section{CONCLUSION}

On the basis of analyzing the concepts and models describing state failures, the opinions of eminent economists, the present empirical data as well as logical conclusions and explanations, we can say that we can confirm the hypothesis according to which the activities of the state directed towards the correction of market failures can often cause an even worse state in comparison to a state possible in the absence of those activities. Also, it has been pointed out that it is not desirable that one be exclusive in their presumption according to which any presence of the state in the economy as a rule only brings harm, or that all active political participants and state official-workers are oriented towards corruption and renting behavior. The research of state failures should not only be seen as the popular revealing of relations, but also as the confronting of the state and the market. It is absolutely unacceptable to simplify the research on the basis of the market or, on the other hand, state fundamentalism.

Economic theory did not pay enough attention, nor did it provide enough space, to the research of the economic streams that were the consequence of the mutual impact of various social and political factors during a long period of time. In the context of internal ties and relations, the political process was often using its own logic that was in many cases incompatible with the logic of optimizing economic mechanisms. Participants in the political life and state official-workers were often not guided by the criteria and motives of reaching an economic efficiency. According to this, the extent of the economic inefficiency and wastefulness was multiply strengthened by the inadequate impact of the political structures, the imperfect coordination of the work of the multiple levels of power, insufficient transparency while reaching decisions within the frames of an unbalanced and rarely renting-motivated behavior of bureaucracy.

The above-mentioned conclusions and attitudes can serve as a good basis for an analysis of the mutual impact of the state and the market in the system of economic relations. Together with this, new conditions for the valid understanding of failures of the state begin to appear. It is also very important to keep in mind the fact that it is necessary that a more complete theoretical explanation of the mutual impact of the centralized and decentralized systems of regulation be presented. In that sense, it is necessary that an interdisciplinary approach in the process of researching the advantages and shortcomings of the mentioned mechanisms be kept, which simultaneously postulates on the understanding of the economic, political and sociological sciences.

The extent of state failures depends on the scope of the state's activity as well as on the form of the political organization of the state, the political culture in particular, the degree of the democratization of the society and the structure of the impact of social institutions. Observed from the aspect of the Republic of Serbia, we can clearly say that this country, as a country in transition, is additionally exposed to numerous problems related to the activating and conducting of state intervention. RS is presently facing numerous causes of state failures, which is accompanied by negative consequences to the efficiency of the economy, the living standard of the population, the functioning of the state etc. We are faced with the day-to-day confirmation of the inefficiency of the mechanisms of collective decision making, which is accompanied by inappropriate coordination between a certain level and parts of the state administration. The control of the accepted measures is severely aggravated, since the state services and the bodies of the lower hierarchical level are commonly in charge 
of conducting them. The Assembly of the Republic of Serbia rarely receives reliable data on conducting the brought decisions, which is why it is prevented from timely reacting and adapting its decisions. Economic inefficiency and numerous problems many public companies are daily faced with confirm the thesis of the non-existence of built-in mechanisms that would ensure the Pareto-efficient allocation of resources.

RS is certainly a representative example when it comes to the question of the non-existence of immediate indicators of the successful work performed by the state organs and public services. It is usually assumed that the value of public goods and services is equal to the state necessary for the functioning of state-owned companies that provide these public goods. The actual problems related to the budget deficit and the plan of the announced savings undoubtedly confirm the fact that, in the public sector, there is an insufficient tie between the state's expenditures and incomes, which is why the space for an inadequate allocation of resources and the occurrence of unnecessary expenditures becomes bigger.

The non-existence of immediate measures of the successfulness of the state's official workers contributes to the low quality and untimely performing of duties, making a favorable basis for corruption to expand. We are witnesses of numerous affairs related to the abuse of authority connected with the business of public companies and the state organs in RS almost at a daily level. The bitter understanding of the facts about the careless behavior of not such a small number of managers in public companies and state officials certainly contributes to the affirmation of the theory of public choice and its firm presumptions about the behavior of participants in the political sphere of the social life, acting in such a way that they reach decisions following their own interests.

The analysis of state failures, first at the theoreticalmethodological level, then from the point of view of the functioning of the domestic economy, should serve the protagonists of the economic policy as a relevant source of information for conducting the economic policy and creating the institute of the market economy. In case the protagonists of the economic policy in RS understand the phenomenology of state failures in the right way, perfect conditions will be created for bringing adequate measures on the basis of which the efficiency of public companies, the efficiency of concrete activities carried out by the state could be calculated, and accordingly, a desirable quality of public goods could be defined. In order to achieve this, it is necessary that the social dimension of the real life circumstances should be appreciated and adequately valued, and together with that, the policy of the efficient state promoted, all this opposed to the ideology of the omnipresent state that always intervenes in cases of market failures and the concept of 'the state for its own sake', which is very popular with politicians.

\section{REFERENCES}

Acemogly, D. (2003). Whay Not a Political Coase Theorem? Journal of Comparative Economics, 31, 620-659.

Alchian, A., \& Demsetz, H. (1973). The Property Right Paradigm. The Journal of Economic History, 33(1), 16-27.

Alesina, A., \& Tabellini, G. (2007). Bureaucrats or Politicans? American Economic Review, 97, 169-179.

Banerjee, A. (1997). A Theory of Misgovernance. Quarterly Journal of Economics, 112(4), 1289-1332.

Bozeman, B. (2002). Public - Value Failure: When Efficient Markets May nor Do. Public Administration Review, 62(2), 145161.

Buchanan, J., \& Tullock, G. (1962). The Calculus of Consent: Logical Foundations of Constitutional Democracy. USA: University of Michigan Press.

Drazen, A. (2000). Political Economy in Macroeconomics. New Jersey: Princeton University Press.

Geanokoplos, J. (2005). Three brief proofs of Arrow's Impossibility Theorem. Economic Theory, 26, 211-215.

Gunning, P. (2002). Understanding Democracy: An Introduction to Public Choice. http://www.fortunecity.com/meltingpot/ barclay/212/votehtm/cont.htm.

Hajek, F. A. (2000). Ekonomija, nauka i politika. Ekonomski anali, 44(147-148), 126-155.

Хайек Ф. (2006). Право, законодательство и свобода. Москва, Россиа: ИРИСЭН, Мысль. 
Hindmoor, A. (2006). Rational Choice. UK: Palgrave Macmillan.

Kitanović, D., Golubović, N., Petrović, D., i Džunić, M. (2011). Savremena politička ekonomija. Niš, Srbija: Ekonomski fakultet.

Коуз, Р. (1993). Фирма, рынок и право. Москва, Россиа: Дело.

Krueger, A. (1990). Government Failures in Development. The Journal of Economic Perspectives, 4(3), 9-23.

Lekovic, V. (2012). Trust as an institutional factor of economic success, Economic Horizons, 14(2), 65-78, doi:10.5937/ ekonhor1202063L

Mankju, G. N. (2004). Principi ekonomije. Beograd, Srbija: Ekonomski fakultet

Myerson R. (1993). Effectiveness of Electoral Systems for Reducing Government Cooruption: A Game Theoretic Analysis. Games and Economic Behavior, 5, 118-132.

Niskanen, W. (1971). Bureaucracy and Representative Government. Chicago: Aldine-Atherton.

Nordhaus, W. D. (1975). The Political Business Cycle. Review of Economic Studies, 42, 169-190.

Olson, M. (1965). The Logic of Colective Action. Harvard University Press.

Petak, Z. (2001). Javna dobra i političko odlučivanje. Zagreb, Hrvatska: Fakultet političkih znanosti.

Pigou, A. (1932). The Economics of Welfare. National Dividend. London, UK: MacMillan.

Posner, R. (1975). The Social Costs of Monopoly and Regulation. Journal of Political Economy, 83(4), 807-827.

Praščević, A. (1999). Teorija političkihciklusa umakroekonomiji. Ekonomski anali, 43(142), 35-53.
Prokopijević, M. (2000). Konstitucionalna ekonomija. Beograd, Srbija: E-Press.

Радыгин, А., \& Энтов, Р. (2012). Провалы государства: теория и политика. Вопросы экономики, 12, 4-30.

Robbins, L. (1962). The Nature and Significance of Economic Science. London, UK: MacMillan.

Rowley, C. K. (2008). Public Choice and Constitutional Political Economy. In C. K. Rowley \& F. Schneider (Eds.), Readings in Public Choice and Constitutional Political Economy (pp 3-30). Springer Science + Bussines Media LLC.

Sekulović, M. (2004). Ogledi o tranziciji. Niš, Srbija: Ekonomski fakultet.

Sen, A. (2004). Racionalnost i društveni izbor. Ekonomski anali, 44(160), 221-253.

Stigler, G. J. (1971). The Theory of Economic Regulation. The Bell Journal of Economics and Management Science, 2(1), 3-21.

Tideman, T. (1997). Voting and the Revelation of Preferences for Public Activities/Perspectives on Public Choice. Cambridge: Cambridge University Press.

Tullock G. (1978). Welfare Effects of Sales Maximization. Economic Inquiry, 16, 113-118.

Tullock G., Seldon. A., \& Brady, G. (2002). Government Failure: A Primer in Public Choice. Washington, DC: Cato Institute.

Vining, A., \& Weimer, D. (1990). Government Supply and Government Production Funciton: A Framework Based on Contestability. Journal of Public Policy, 10, 1-22.

Weber, M. (1958/1921). From Max Weber. Oxford, UK: Oxford University Press.

Wolf, C. (1979). A Theory of Nonmarket Failure. Journal of Law and Economics, 22(1), 107-139.

Received on $29^{\text {th }}$ May 2013, after revision, accepted for publication on $26^{\text {th }}$ August 2013

Dragan Petrovic is an associate professor at the Faculty of Economics, University of Nis, in the Political Economy course. He obtained his PhD degree in institutional economics, at the Faculty of Economics, Unviersity of Nis. Key areas of his scientific interests include the relevant issues of institutional economics, economic system and policy. 


\title{
KLJUČNI TEORIJSKI I PRAKTIČNI ASPEKTI DRŽAVNIH NEUSPEHA U SAVREMENOJ EKONOMIJI
}

\author{
Dragan Petrović* \\ Ekonomski fakultet Univerziteta u Nišu
}

Predmet ovog rada jeste analiza evolucije pristupa problemu državnih neuspeha. Reč je o fenomenu proisteklom iz koncepcije tržišnih neuspeha, koji se u ekonomskoj teoriji može posmatrati u kontekstu traganja za novim strategijama političko-ekonomskih mehanizama alokacije resursa. U vezi s tim, posebna pažnja biće usmerena na identifikaciju komponenata institucionalnog uticaja na efikasnost ekonomskih procesa, što najpre podrazumeva generalni osvrt na ulogu države u ekonomiji. Multidisciplinarni pristup istraživanju ovako kompleksnog pitanja, između ostalog, zahteva uvažavanje ključnih informacionih problema prilikom analize ekonomskih funkcija javnog sektora, realno sagledavanje mogućnosti finansiranja mera državne politike, adekvatno vrednovanje uloge političkog procesa i uticaja rentijerski orijentisanog ponašanja državnih službenika, $\mathrm{i}$, $\mathrm{u}$ konačnom, pokušaj identifikovanja negativnih eksternih efekata nastalih usled odsustva, ali i prisustva državne koordinacije u ekonomiji.

Ključne reči: državni neuspesi, teorija javnog izbora, mehanizam kolektivnog odlučivanja, informacioni problemi

JEL Classification: D72, D73, D74, H41

\section{UVOD}

Pozivi za ograničavanjem aktivnosti države u sferi privređivanja postojali su još u periodu nastanka i ustanovljavanja tržišne ekonomije. Poznato je da su predstavnici fiziokratizma bili saglasni da je zadatak države da obezbedi uslove za funkcionisanje slobodne i neograničene konkurencije. Značaj klasične škole u tom smislu je još važniji imajući u vidu da u ekonomskoj teoriji vlada mišljenje da je ona ponudila suštinske

\footnotetext{
* Korespondencija: D. Petrović, Ekonomski fakultet Univerziteta u Nišu, Trg kralja Aleksandra 11, 18000 Niš, Srbija; e-mail: dragan.petrovic@eknfak.ni.ac.rs
}

odredbe o funkcijama države u tržišnoj ekonomiji. A. Maršal je uveo pojam "eksterni efekti", sa namerom da ukaže u kojoj meri oni mogu ograničiti sferu tržišne regulacije. A. Pigou je smatrao da postojanje takvih efekata otežava odvijanje normalnih ekonomskih procesa, umanjujući mogućnosti rasta nacionalnog dohotka (Pigou, 1932, 173). Pomenute konstatacije o tome da tržište ne može svojim slobodnim delovanjem dovesti do optimalne alokacije resursa poslužile su kao osnova za formulisanje pojma poznatog kao tržišni neuspesi.

Postojanje tržišnih neuspeha je ključni argument za intenziviranje državne intervencije, tj. aktiviranje tzv. netržišnih rešenja. Empirijski gledano, tokom 
XX veka realno širenje privrednih funkcija države bilo je uslovljeno, pre svega, snažnom privrednom depresijom i burnim ratnim dešavanjima. Međutim, i posle okončanja Drugog svetskog rata, nastavljena je tendencija rasta uloge države u ekonomiji.

Predstavnici liberalnog pravca ekonomske misli oštro su istupili protiv snažne i neprimerene državne intervencije u ekonomskoj sferi društvenog života. Ukazivali su na postojanje negativnih posledica državne aktivnosti, što je pobudilo neke ekonomiste da paralelno kategoriji poznatoj pod nazivom tržišni neuspesi formulišu njoj alternativnu kategoriju tzv. državnih neuspeha. Imajući u vidu navedeno, predmet istraživanja ovog rada usmeren je na ispitivanje potencijalnih faktora relativne efikasnosti tržišnog $\mathrm{i}$ državnog mehanizma alokacije resursa, $i$ to $u$ situacijama kada tržište svojim slobodnim delovanjem ne može dovesti do optimalnih ekonomskih i društvenih posledica. Stoga se kao ključna hipoteza od koje se $u$ radu polazi odnosi na to da državna politika, usmerena na korekciju tržišnih neuspeha, može zapravo prouzrokovati još lošije stanje u odnosu na ono koje bi bilo u slučaju odsustva te iste politike. To znači da neuspesi tržišta ne moraju predstavljati $a$ priori argument za tzv. netržišna rešenja.

Osnovu ovog istraživačkog pristupa predstavljaće teorijska, strukturna analiza predmeta istraživanja na bazi elaboracije dostupnih sekundarnih izvora. To znači da će, u cilju testiranja navedene hipoteze, biti korišćena empirijska istraživanja različitih autora koji su se bavili ovom problematikom. Potom će se kombinacijom istorijsko-deduktivnog metoda, koji polazi od utvrđenih činjenica, i hipotetičkodeduktivnog, u čijoj su osnovi određene pretpostavke, doći do generalnih zaključaka vezanih za neophodnost državne intervencije u slučaju "otkaza" tržišta. Pri tom će posebna pažnja biti posvećena komparativnoj analizi jedne i druge varijante upotrebe i usmeravanja resursa, što $\mathrm{u}$ konačnom treba da ponudi valjan odgovor na pitanje da li je i kada potrebno supstituisati tržište kada ono ne dovodi do Pareto efikasnosti.

\section{POJMOVNO ODREĐENJE TRŽIŠNIH I DRŽAVNIH NEUSPEHA}

Na širenje državnog preduzetništva i centralizovane regulacije, predstavnik savremenog liberalizma F. Hajek (2000) gleda, pre svega, kao na proces kojim se narušavaju prava građana i ograničavaju slobode tržišnih učesnika. Njegov rigidni stav protiv državnog intervencionizma počiva na pretpostavci da je tržište superiorniji koordinacioni mehanizam od nepouzdanog državnog planiranja. Logika ovakvog pristupa je da su individue svesne svojih preferencija, troškova i relativnih cena, dok državni planeri ako žele da supstituišu tržišni mehanizam moraju znati daleko više. Dok u cenovnom sistemu svaki pojedinac mora da razume samo svoju sopstvenu situaciju, planer treba da uvaži interese svih. Društveni život, a naročito njegova ekonomska sfera, prilično su kompleksni, iz čega proizilazi da planeri svoje strategije zasnivaju na ograničenim, nedovoljnim i fragmentarnim znanjima i informacijama. Stoga se lako može dogoditi da aktivnosti "dobronamernih" vlada rezultiraju neželjenim posledicama i opadanjem društvenog blagostanja.

Osim informacionih i kognitivnih problema, vezanih za kreaciju i sprovođenje državnih mera u privredi, neophodno je osvrnuti se i na troškove državne regulacije. Za razliku od neposrednih rezultata mešanja u tržišni poredak, koji su u većini slučajeva prilično očigledni, mnogi posredni efekti ostaju nepoznati. Kako tvrdi F. Hajek "nama nije omogućeno da znamo sve troškove uzrokovane intervencijom države u sferi ekonomije" (Хайек, 2006, 75).

Uvažavanje negativnih posledica državne aktivnosti uticalo je na to da se u ekonomskoj teoriji formuliše kategorija tzv. državnih neuspeha. Najpre je C. Wolf (1979) predložio koncepciju netržišnih neuspeha, da bi se kasnije sve više koristio termin državni neuspesi. Fenomen državnih neuspeha implicira to da kad god zakonodavci i članovi vlade donose odluke o intervenisanju povodom određenih tržišnih nedostataka, oni često prave još veće greške (Gunning, 2002). O različitim uzrocima i oblicima državnih neuspeha, između ostalih, pisali su i predstavnici teorije društvenog izbora (Tullock et al, 2002). 
Vremenom je problem državnih neuspeha sve više zaokupljao pažnju ekonomista, i to u meri da su neki autori nedostatke državne regulacije stavljali $u$ isti rang sa tržišnim nedostacima. Ima mišljenja da su modeli državnih neuspeha, po svojim zadacima i metodama proučavanja, potpuno analogni teoriji tržišnih neuspeha. Štaviše, umnogome se podudaraju i analitička dostignuća tih modela, kao i njihove slabosti (Bozeman, 2002, 157). Indikativno je i to da su mnogi ekonomisti, koji su ranije zastupali tezu o nephodnosti državne intervencije $u$ ekonomiji povodom tržišnih nedostataka, sada glasnogovornici dijametralno drugačijeg stava: nepovoljne posledice, povezane sa državnim neuspesima, mogu biti ozbiljnije nego što je to u slučaju postojanja tržišnih neuspeha (Радыгин \& Энтов, 2012, 6).

Postojanje državnih neuspeha iznova aktuelizuje koncepciju tržišnih neuspeha, zbog čega njihovo međusobno poređenje $u$ izvesnom smislu poprima karakter "večitog" pitanja, čineći i dalje otvorenom diskusiju o tome da li država treba da interveniše uvek kada postoje tržišni neuspesi. Preispitivanje se još više odnosi na to koje teorijske pretpostavke stoje u osnovi koncepcije o državnim neuspesima.

Realno suočavanje sa tržišnim neuspesima uticalo je na pojavu teorijskih modela po kojima država pomoću netržišnih metoda može obezbediti tržišnu ravnotežu. Pozitivan stav o potrebi mešanja države u slučaju tržišnih nedostataka imali su, manje ili više eksplicitno, i mnogi predstavnici vladajuće ekonomske teorije počev od tzv. marginalističke revolucije. Nagomilano iskustvo o brojnim državnim neuspesima aktuelizovalo je ovo pitanje ne na nivou supstitucije tržišta u slučaju kada ono ne dovodi do Pareto efikasnosti, već na nivou poređenja jedne i druge varijante upotrebe i usmeravanja resursa.

Metodološki posmatrano, neophodno je uporediti teorijski model, koji pretpostavlja da država u slučaju postojanja tržišnih neuspeha može maksimizirati društveno blagostanje, sa teorijskim modelom slobodne privrede, baziranom na maksimizaciji individualne koristi i profita (Tullock, 1978). S jedne strane, tržišne sile ne mogu obezbediti adekvatnu ponudu određenih dobara. S druge strane, funkcionisanje decentralizovanih tržišnih mehanizama, $u$ principu, zahteva manju količinu potrebnih informacija za donošenje odluka na tržištu. S tim u vezi, potrebno je odgovoriti na sledeća pitanja: koje mehanizme maksimizacije društvenog blagostanja je moguće koristiti i da li je realno kontrolisati delovanje tih mehanizama?

\section{INFORMACIONI PROBLEMI I KREIRANJE NETRŽIŠNIH REŠENJA}

U postupku analize javnog sektora ključno pitanje odnosi se na problem prikupljanja i obrade informacija neophodnih za izbor načina na koji će država reagovati u konkretnom slučaju. Situacija $\mathrm{u}$ tom smislu principijelno je različita $\mathrm{u}$ odnosu na uobičajenu praksu u sferi privatnog preduzetništva. Analizirajući funkcionisanje tržišnih mehanizama, savremena ekonomska teorija ukazuje na to kako se $u$ procesu delovanja tržišnog mehanizma javljaju realne pretpostavke na kojima svoje poslovanje baziraju pojedinačni ekonomski učesnici. Međutim, kada državna preduzeća proizvode dobra koja tržište ne može obezbediti, onda su, po pravilu, informacije o preferencijama tržišnih učesnika nepotpune ili izostaju. Postojeći metodi ispoljavanja individualnih "netržišnih" preferencija ne omogućavaju izradu mehanizama sposobnih da doprinesu povećanju alokativne efikasnosti.

Ukoliko bi učesnici ekonomskih procesa časno govorili o svojim preferencijama, to bi obezbedilo informacije neophodne za ostvarenje poboljšanja po Paretu. Međutim, bilo kakva sumnja $u$ to da će ponuđena informacija biti korišćenja za poboljšanje po Paretu, uticaće na ljude da možda ponude netačne i nedovoljno pouzdane informacije (Tideman, 1997, 237). Ukoliko bi se, recimo, sprovela anketa grupe potencijalnih korisnika o njihovim preferencijama, a samim tim i o njihovoj graničnoj spremnosti za plaćanje, onda bi se, verovatno, utvrdilo da pojedinci imaju interesa da prikažu da je njihova granična korisnost od potrošnje date količine jednog dobra daleko manja, kako bi se smanjio iznos koji plaćaju za njegovo korišćenje. I suprotno, ukoliko ne bi plaćali, pojedinci bi preuveličavali svoju korisnost od javnog dobra. 
Izgradnja puta je primer koji uzima G. N. Mankju $(2004,229)$ u nameri da ukaže na postojanje ozbiljnih poteškoća koje prate državu prilikom odmeravanja koristi i troškova vezanih za obezbeđenje javnih dobara. Kako on kaže, nije pouzdano ni jednostavno pitati ljude koliku bi vrednost pripisali budućem autoputu. Oni koji bi koristili autoput podstaknuti su da navedu preveliku vrednost koju bi stekli izgradnjom autoputa. Oni koji bi bili oštećeni izgradnjom autoputa imaju podsticaj da navedu prevelike troškove koje bi zbog toga snosili kako bi sprečili njegovu izgradnju. Ispada, dakle, da smo svi za bezbednije ulice, ukoliko ne moramo da snosimo troškove (Kitanović i ostali, 2011, 53). Kada je u pitanju Republika Srbija (RS), upečatljivo je da većina građana podržava postojanje javnog servisa, ali ne i plaćanje televizijske pretplate.

Prethodni problemi, po pravilu, rezultiraju brojnim poteškoćama kako u procesu prikupljanja i odgovarajućem korišćenju informacija o preferencijama tržišnih učesnika, tako i prilikom formiranja osnove na kojoj bi se bazirala državna aktivnost i procedura javnog izbora. A od preciznosti $\mathrm{u}$ identifikovanju individualnih, odnosno, društvene preferencije za javnim dobrom, zavisi da li će ponuđena količina javnog dobra biti blizu društveno optimalne.

Obezbeđivanje javnih dobara putem javnog sektora pravda se razlozima obezbeđivanja društveno optimalne količine ovih dobara. Međutim, upravo oni problemi koji tržište čine neefikasnim i koji predstavljaju argument $u$ korist netržišnih rešenja, javljaju se i kod obezbeđivanja ovih dobara u javnom sektoru. Tu se misli, pre svega, na gotovo nerešive probleme prikupljanja informacija. Bez ispravne procene preferencija, ni decentralizovano tržište ni javni sektor, ne mogu da obezbede Pareto-optimalnu količinu javnog dobra.

Ispravna procena preferencija kada su u pitanju javna dobra prevashodno se tiče pitanja da li je moguće definisanje integralne društvene preferencije iz raznovrsnih individualnih preferencija. Neoklasična ekonomija je rešavanje ovog problema bazirala na maksimalnom uvažavanju tzv. utilitarne tradicije. U suštini, reč je o nastojanju da se izvedu konzistentne društvene preferencije na osnovu individualnih preferencija, $\mathrm{i}$ to agregiranjem ukupnog nivoa korisnosti svih ljudi o kojima je reč. To automatski znači da nema nikakvih poređenja individualnih preferencija, pa je "ekonomija blagostanja" počivala samo na jednom osnovnom kriterijumu poboljšanja Paretovom kriterijumu. Međutim, tu izostaju stavovi o raspodeli društvene korisnosti i svim ostalim faktorima koji nemaju uticaja na generisanje te korisnosti, zbog čega je ovakvo objašnjenje izloženo oštrim kritikama (Sen, 2004, 343).

Veliki doprinos analizi procesa kolektivnog odlučivanja i sistema društvenih preferencija dali su K. Arrow i J. Buchanan. K. Arrow je najpre izrazio sumnju u mogućnost formiranja agregatnih vrednosnih sudova o društvenom blagostanju, pitajući se da li postoji valjana procedura društvenog odlučivanja koja u razumnoj meri poštuje individualne vrednosti i preferencije?

U pokušaju da odgovori na ovo pitanje, K. Arrow navodi da za definisanje integralne društvene preferencije iz raznovrsnih individualnih preferencija nisu ispunjeni uslovi, posebno oni koji se odnose na poželjna svojstva glasačkog sistema. Obeležja kao što su jednoglasnost, tranzitivnost, nezavisnost od nebitnih alternativa i nepostojanje diktatora ne može zadovoljiti nijedan glasački sistem, što je $u$ literaturi nazvano Arrow-a "teorema nemogućnosti" i bilo praćeno brojnim pokušajima verifikacije iznetih tvrdnji i dokaza (Geanakoplos, 2005, 212).

\section{PROBLEM FINANSIRANJA JAVNIH DOBARA}

Prilikom izučavanja mehanizama funkcionisanja javnog sektora, posebnu ulogu ima odgovor na pitanje koje se tiče mogućnosti pouzdanog finansiranja državnih mera vezanih za obezbeđenje javnih dobara. Klasičan pristup posvećen je, pre svega, problemu "pravdenog oporezivanja". Pretpostavlja se da suma poreza, koju snosi svaki učesnik u cilju obezbeđenja javnih dobara, treba da bude $\mathrm{u}$ direktnoj srazmeri sa individualnim preferencijama vezanim za ta dobra. Ovakvim pristupom se uobičajeni principi tržišnih odnosa među privatnim licima prenose na sferu državnih finansija, dok se porezi tretiraju kao 
individualne, $\mathrm{tj}$. personalizovane cene usluga koje pruža država, odnosno, državna preduzeća. No tada lica (ili preduzeća) koja ne dobijaju dovoljno koristi od funkcionisanja određenog javnog dobra, ili, pak, nisu saglasni sa preuzetim obavezama njihovog finansiranja, mogu odustati od uplate odgovarajućih poreza.

Ispostavlja se, dakle, da u samoj prirodi javnih dobara postoji protivurečnost (Petak, 2001, 18). Karakteristika neiscrpivosti, odnosno zajedničke ponude, podstiče sve pripadnike zajednice na saradnju po pitanju obezbeđenja javnih dobara. O kojim god javnim dobrima da se radi, svim članovima zajednice biće bolje ako doprinose stvaranju tih dobara. Istovremeno, nepostojanje efikasnih mehanizama isključivanja utiče na pojavu "slobodnih korisnika“, odnosno, onih koji koriste javno dobro, ali ne žele da učestvuju u njegovom finansiranju. Zato je obezbeđenje javnih dobara skopčano sa fudamentalnim principom - kako se gotovo ceo iznos državnog budžeta ostvaruje nedobrovoljnim putem, poreski obveznici u demokratskim državama žele da "osete" neposrednu povezanost između dela dohotka kojim plaćaju poreze i pripadajućim koristima koje dobijaju po osnovu potrošnje javnih dobara. Međutim, sve do aktuelnog vremena ostala su ozbiljna razmimoilaženja između preferencija poreskih obveznika i budžetske politike države. To se može protumačiti na način da naknada za korišćenje javnih dobara nije $\mathrm{u}$ direktnoj vezi sa obimom njihovog korišćenja. Umesto na tržištu, odluka o tome kolika će biti ponuda javnog dobra donosi se $\mathrm{u}$ političkoj sferi društvenog života. Stoga u većini demokratskih zemalja, građani ne mogu određivati vrstu javnih dobara koju žele, kao i njihovu količinu i kvalitet. Priroda javnih dobara je takva da pojedinac ima malo izbora u pogledu potrošnje, odnosno, mora prihvatiti datu količinu i kvalitet javnog dobra koja se nudi.

U osnovi konflikta između individualnih preferencija i državnih odluka u pogledu javnih dobara stoji, dakle, problem zajedničkog fonda. Naime, predstavnici izvršne vlasti mogu koristiti zajednički fond postupajući po svom nahođenju, odnosno, ignorišući interese korisnika dobara koji se finansiraju iz tog zajedničkog fonda. Zato se može reći da praktična rešenja $u$ domenu javnih dobara $u$ nemalom stepenu zavise od političkog uređenja zemlje.

\section{KOORDINACIJA, KONFLIKTI I ULOGA RENTIJERSKOG PONAŠANJA}

Prema koncepciji društvenog blagostanja i drugih analognih teorijskih modela, država istupa u obliku jedinstvenog političkog instituta koji je ovladao monopolskim pravom korišenja prinude na datoj teritoriji (Weber, 1958; 1921, 78). Kada se ima u vidu ekonomska sfera društvenog života, najpre se može pomenuti neoklasična definicija da je "Ekonomija nauka o ljudskom ponašanju kao odnosu između ciljeva i ograničenih resursa koji imaju mogućnost alternativne upotrebe" (Robbins, 1962, 16). Shvatanje o tome da se ekonomija bavi optimalnom upotrebom ograničenih resursa sadrži pretpostavku da kada se pronađe optimalno rešenje, tj. optimalna ekonomska politika, ona će biti i primenjena (Drazen, 2000). To znači da je ključni izazov ustanovljavanje optimalnih mera, a ne i realizacija istih, zbog čega se problem izbora odgovarajuce ekonomske politike svodi na tehnički problem.

Praksa, međutim, najčešće demantuje tezu o postojanju idealne države čiji predstavnici isključivo nastoje da ostvare interese građana. Najpre treba konstatovati da funkcionisanje države pretpostavlja izuzetno složen hijerarhijski sistem. Delovanje različitih, često prilično fragmentiranih nivoa vlasti (zakonodavne, izvršne, sudske), po pravilu, nije dovoljno koordinirano, dok u nekim slučajevima postoji direktna protivurečnost $u$ procesu ostvarenja njihovih ciljeva i zadataka.

Pored objektivnih poteškoća koje prate proces organizovanja donošenja i sprovođenja državnih odluka, postoje i drugi razlozi poželjnog odsustva državne intervencije. Naime, postoji sumnja da primenjena makroekonomska politika neće odgovarati optimalnim rešenjima, ne zbog tehničkih ili informacionih ograničenja, već usled političkih prepreka. Političke prepreke odnose se na sukob individualnih interesa u društvu, kao i na neophodnost da se napravi jedinstveni društveni izbor u uslovima prisustva suprotstavljenih interesa. Najpre, oštre 
protivurečnosti između izvršne i zakonodavne vlasti mogu rezultirati odsustvom jedinstvene strategije i, u tom smislu, optimalnog ekonomskog razvitka. Odgovarajuće "njihanje" privrednog sistema, pojačano uticajem političkih ciklusa i populističke politike, neizbežno povlači sa sobom dopunske troškove i snižavanje nivoa društvenog blagostanja.

U uslovima koji dopuštaju mogućnost sprovođenja legalnih tržišnih aktivnosti, konflikt regionalnih i drugih individualnih interesa mogao bi se regulisati ostvarivanjem komercijalne saglasnosti i odgovarajućim sistemom naknada i plaćanja po sistemu tzv. Kouzove teoreme. Naime, za razliku od države koja može da "otkaže", tržište je, kako smatra R. Kouz (Koy3, 1993, 142), sposobno da svaku inicijalnu alokaciju resursa prevede u Paretov optimum. Prema tom mišljenju, zainteresovane strane, između kojih postoje određeni problemi i sukobljeni interesi, mogu same doći do rešenja pregovaranjem, bez intervencije države. Uslov za to su jasno definisana svojinska prava i niski transakcioni troškovi.

Suština Kouzove teoreme ogleda se, dakle, $\mathrm{u}$ tome što naglašava vezu privatne svojine sa ostvarivanjem opštih društvenih interesa, iznoseći argumente protiv uplitanja države $u$ rešavanje problema između ekonomskih subjekata. To se objašnjava činjenicom da uspešna realizacija svojinskih prava, zapravo, inicira individue da prilikom donošenja odluka o pokretanju ekonomskih aktivnosti imaju u vidu ukupne društvene troškove (Alchian \& Demsetz, 1973, 24).

U političkoj sferi, međutim, ne postoji oslanjanje na funkcionisanje Kouzovih tržišnih mehanizama, koji obezbeđuju kretanje, tj. napredovanje ka optimalnom rešenju (Acemogly, 2003). Pomoću standardnih modela teorije igara nije teško pokazati da ravnoteža u smislu Neša u određenim situacijama pretpostavlja utvrđivanje neoptimalnog (srazmerno velikog) broja aktivnosti i relativno duge rokove uvođenja i funkcionisanja istih. U velikom broju slučajeva država potvrđuje navedenu tendenciju, šireći svoju aktivnost izvan optimalnih granica delovanja (Радыгин \& Энтов, 2012, 12).

U okvirima savremene političke ekonomije je zato ponuđeno istraživanje o uticaju političkih ustanova na ekonomske ishode i rezultate, što, između ostalog, podrazumeva i interesovanje vezano za pojavu neadekvatnih i "iskrivljenih" odluka zakonodavnih i izvršnih vlasti. Često se kroz donošenje takvih odluka realizuju aktivnosti usmerene na ostvarivanje određenih pogodnosti, odnosno sticanje profita mimo tržišta i tržišnih aktivnosti, što je u literaturi poznato kao traganje za rentom (rent-seeking). Prilike za sticanje rente javljaju se zahvaljujući zakonodavnoj aktivnosti države, tj. njenih tela, trgovinskim ograničenjima, subvencioniranju, regulaciji, preraspodeli itd.

Traganje za rentom jeste tipičan mehanizam nametanja partikularnih interesa kao društvenih (Prokopijević, 2000, 324) i, kao takvo, prilično je zastupljeno u domenu donošenja i sprovođenja zaštititnih mera u spoljnoj trgovini. Naime, postoje istraživanja koja pokazuju očiglednu inertnost i stabilnost rentnih dohodaka vezanih za sprovođenje protekcionističkih mera trgovinske politike (Krueger, 1990). Zahvaljujući takvoj situaciji smanjuje se konkurentnost na domaćem tržištu, sužava raznovrsnost ponude i smanjuje kupovna moć potrošača, koji teret visokih cena snose $\mathrm{u}$ dugom roku. Pored toga, protekcionizam ima negativan uticaj na raspodelu dohotka, jer dovodi do preraspodele dohotka od potrošača i nezaštićenih grana ka zaštićenim granama privrede.

Troškovi traganja za rentom mogu biti prilično visoki, i zavise od mnoštva faktora kao što su stepen regulacije privrede, pravna sigurnost, broj i struktura ograničenja i zabrana, običaji, nivo blagostanja itd. Neki modeli teorije igara, u kojima se izučava uticaj rentijerski orijentisanog ponašanja prilikom donošenja odluka u okviru različitih izbornih sistema, iznos renti dovode $u$ vezu sa brojem političkih aktera koji učestvuju na izborima. Shodno tome, veličina ravnotežne rente suštinski zavisi od intenziteta konkurencije između različitih društvenih grupa na političkoj areni: sa umanjenjem broja kandidata na izborima pri određenim pretpostavkama neizbežno je uvećanje ranotežne rente koju prisvajaju akteri političkog života (Myerson, 1993). Visina renti i problemi rentno orijentisanog ponašanja povezani su i sa izborom između centralizovanih i decentralizovanih mehanizama regulacije. Što je sklonost riziku od strane učesnika privrednog procesa niža, to centralizovana alokacija resursa i državni aparat potražuju značajnije stimulacije za vladine činovnike i višu političku rentu, 
što, sa svoje strane, uzrokuje dopunske troškove i vodi sniženju državnog blagostanja.

\section{ULOGA POLITIČKOG PROCESA}

Suštinski značaj za pojavu državnih neuspeha mogu imati obeležja političkog procesa, prevashodno ona vezana za način donošenja i kontrolu vladinih odluka. Najpre treba konstatovati da svetom političkih rešenja "gospodari" zasebna logika, zasnovana na obrazloženju pedloženih mera, a što može prilično odstupati od strogih ekonomskih razmišljanja o uticaju istih na efikasnost funkcionisanja privrede $i$ porast društvenog blagostanja.

Razmatrajući granice državne regulacije nije teško uočiti da u mnogim zemljama postoje prilično čvrste institucionalne veze između vlade i relativno manje efikasnih korporacija, prvenstveno onih koje se nalaze u državnom vlasništvu. Empirija pokazuje da su ta preduzeća, po pravilu, jako zainteresovana za različite forme centralizovane podrške. $S$ druge strane, uticajnoj politici i visoko rangiranim državnim činovnicima $\mathrm{u}$ određenim situacijama može zatrebati aktivna podrška tzv. "svojih" kompanija.

Izmena opštih uslova privrednog razvitka može umanjiti potrebu za centralizovanom regulacijom. Međutim, birokratski aparat koji je u tom sistemu delovao, zainteresovan je da sačuva i proširi svoje nadležnosti i funkcije. Time se, s jedne strane, postiže dodatno osiguranje radnog mesta, a s druge strane, pokazuje sopstvena važnost. Kada birokrata zatraži povećanje broja zaposlenih, što se pravda preopterećenošću osoblja, poboljšanjem i povećanjem obima usluga, teško se može proveriti verodostojnost takvih tvrdnji. Za neke poslove nema egzaktnih pokazatelja, za druge ima više pokazatelja, te se često ocena o radu i efikasnosti nekog birokrate zasniva na intuitivnom utisku njegovih pretpostavljenih (Kitanović i ostali, 2011, 75). Rast birokratije je, dakle, endogeni proces po kome su birokratski aparat, administrativne ustanove i državna preduzeća potčinjeni zakonima funkcionisanja ogranizacije. U prirodi sistema jesu određeni ciljevi, ali i formiranje dopunskih strategija njihovog samoočuvanja.
Proces donošenja zakona i drugih državnih odluka prolazi kroz složenu i prilično razuđenu proceduru odlučivanja. U slučaju da neke političke snage i državni organi uskrate podršku donošenju određenih zakona, velika je verovatnoća pravljenja izvesnih kompromisa $\mathrm{u}$ pravcu navodnog poboljšanja pedloženih zakonskih rešenja. Kroz takvo političko usklađivanje i "doterivanje", između ostalog, može biti sužena sfera delovanja upravo onih mehanizama koji treba da "očiste put" u pravcu Pareto optimalnih izmena.

Kada je u pitanju proces donošenja političkih odluka, u teorijskim modelima savremene političke ekonomije pravi se razlika između političara i birokrata. Suština je da konkretno delovanje i jednih i drugih može poprimiti izvestan nivo samostalnosti u pogledu oficijelnog proglašavanja prioriteta državne politike. U vezi s tim, neizbežno je pokrenuti pitanje o optimalnom razgraničenju državnih funkcija između političara i birokrata, kao i odgovarajućim kriterijumima optimalnosti (Alesina \& Tabellini, 2007). Iako se na birokrate često gleda kao na pouzdane $\mathrm{i}$ delotvorne izvršioce postavljenih zadataka koji deluju u okviru određene hijerarhije i u skladu sa tačno definisanim pravilima, oni de facto značajno utiču na politički proces. Razlog za to jeste taj što stranke dolaskom na vlast ne mogu neposredno da sprovode svoje politike, već je sprovođenje političkih odluka u nadležnosti birokratije. Ispostavlja se, dakle, da je veliki deo administrativnog posla ostavljen državnim službenicima, zbog čega oni imaju značajnu slobodu u odabiru načina na koji će sprovoditi političke odluke. Zato se može reći da delimično modifikovana šema tzv. principal-agent problema jeste primenljiva $\mathrm{i} u$ analizi funkcionisanja javnog sektora. Strukturu predloženog modela činili bi aktivna individua birokrata, s jedne strane, i neki apstraktni politički insitut, koji se uzdiže nad njim i kontroliše ga - država (Banerjee, 1997). U takvom sistemu postoji svojevrsna asimetrična informisanost - birokrate su, po pravilu, bolje upućene u stvarne probleme nego što su to njihovi pretpostavljeni. To znači da mogu da manipulišu time koliko, kada i pod kojim uslovima svoje znanje stavljaju na raspolaganje pretpostavljenima. Kako političari odluke donose na osnovu raspoloživih informacija, to birokrate mogu značajno da utiču na sadržaj donetih odluka. Oni mogu da kontrolišu tok informacija i da 
političarima plasiraju samo one informacije koje su $u$ interesu birokratije.

Problem se, nažalost, ne svodi samo na asimetrično delovanje državnih činovnika. Ne manju ulogu u svemu tome ima i delovanje različitih društvenih slojeva i grupa, gde pojedine grupe mogu značajno uticati na sprovođenje državne politike. Naime, suštinsku ulogu u izboru makroekonomske strategije mogu imati politički razlozi taktičkog karaktera usmereni na "makimizaciju popularnosti". Pomenuta povezanost može rezultirati političkim ciklusom koji se zasniva na pretpostavci da partija koja se nalazi na vlasti u cilju uvećanja svojih šansi na reizbor izaziva pad nezaposlenosti, da bi, zatim, posle izbora odustala od delovanja usmerenih na povećanje zaposlenosti (Nordhaus, 1975). Sam proces promena u nivou zaposlenosti, aktuelni kreatori ekonomske politike sprovode monetarnom i fiskalnom ekspanzijom pre izbora, dok će inflacija početi da raste neposredno nakon izbora (Praščević, 1999).

Nije teško zaključiti da društveno-političko „manevrisanje" u cilju ostvarivanja taktičkih ciljeva u mnogim slučajevima ne samo što uzrokuje tekuću privrednu nestabilnost, već može imati katastrofalne dugoročne posledice. Ekstremno uprošćavanje političkih argumenata još više sužava krug realnih mogućnosti za doslednu realizaciju dugoročne ekonomske strategije. U takvim okolnostima, odgovarajuće i sasvim obrazložljive mere vladine politike neretko gube sistematičnost i fundiranost, postajući irelevantne sa stanovišta ekonomske logike.

U sklopu ekonomskih istraživanja tokom 80 -ih godina XX veka, naročita pažnja bila je posvećena suštinskim protivurečnostima $u$ pretpostavkama, na kojima se bazira teorija funkcionisanja javnog sektora. S jedne strane, opštepriznata teorija u svom opisu delovanja tržišnih učesnika polazi od standardne ciljne funkcije karaktristične za interese tzv. „ekonomskog čoveka“. S druge strane, kao učesnici netržišnih operacija obično figurišu subjekti koji nemaju sopstvene privatne interese $u$ obavljanju tih poslova, i pri tom ne postoji bilo kakva sumnja u njihove profesionalne sposobnosti.

Izučavanje složenog kompleksa motiva, kojima se $\mathrm{u}$ svom delovanju rukovode predstavnici vlasti i državni činovnici, vodi zaključku da razradu strategija i realizaciju državnih funkcija pomenuti subjekti ne ostvaruju uvek savesno i profesionalno. Kako u obavljanju poverenih poslova oni mogu imati sopstvene interese, kao polazna hipoteza uzima se to da birokrate, kao i akteri u privatnom sektoru, deluju racionalno rukovodeći se sopstvenim interesima (Niskanen, 1971). Na ovaj način afirmiše se ekonomija javnog izbora kao relativno nova nauka nastala iz dve etablirane nauke - političke teorije i ekonomije. Ona se bavi svrsishodnošću primene ekonomske analize na političko odlučivanje (Buchanan \& Tullock, 1962, 7), nastojeći da metodološke pretpostavke ekonomske nauke primeni na proces donošenja kolektivnih odluka, gde su osnovni učesnici političke partije, birači, političari, interesne grupe i birokratija.

Rentijerski rukovođeno ponašanje političkih činilaca i činovnika dobija na intenzitetu sa širenjem nadležnosti države, kada jedno od sredstava konkurencije među privatnim preduzećima postaje veza sa strukturama vlasti. Tako građeni odnosi između države i privrednih subjekata, po pravilu, još više ograničavaju efikasnost funkcionisanja državnih organa u sferi privređivanja. Učinak državne birokratije, između ostalog, dovodi se $\mathrm{u}$ vezu i sa postojanjem različitih prioriteta privredne delatnosti u državnom i privatnom sektoru. Dok je privatni vlasnik neposredno zainteresovan za ekonomiju resursa, rukovodioci državnih organa i kompanija nastoje da ne dozvole da im neki deo pripadajućih budžetskih sredstava ostane neutrošen, odnosno, bude iskorišćen za druge namene.

Što je širi obim državnih nadležnosti i operacija, odnosno, veći obim proizvodnje u državnom sektoru, to značajniju ulogu mogu imati troškovi delegiranja nadležnosti, što uključuje i tzv. X-neefikasnost (Vining \& Weimer, 1990). Radi se o neefikasnosti uzrokovanoj slabljenjem konkurentskih mehanizama i tržišne discipline, što dovodi do toga da skoro svi troškovi kompanija poprimaju karakter opravdanosti u pravcu optimizacije ciljnih funkcija.

Među važnije faktore koji utiču na snižavanje efikasnosti rada državnih organa svakako spada i izrazita nesklonost riziku od strane tipičnog državnog činovnika. Kako kriterijumi ocenjivanja posledica netrivijalnih rešenja mogu biti prilično rastegljivi, verovatnoća nepovoljnih ishoda suštinski se povećava. 
To potiskuje korisne inicijative od strane činovnika, i uzrokuje prethodna preispitivanja, usaglašavanja i pokretanja brojnih osiguravajućih procedura, što u prinicipu dovodi do odugovlačenja donošenja odluka, ograničavajući njihovu delotvornost.

Monopolski položaj mnogih vladinih tela i državnih organa i odsustvo tržišne konkurencije ne znači da nema suparničkih odnosa među tim zasebnim, formalno potpuno razdvojenim kolektivitetima. Težeći da prošire svoju delatnost i uticaj u uslovima ograničenih budžetskih resursa, mnogi državni organi i njihovi rukovodioci nastoje da "otesne" svoje planove ili da "progutaju" ostala državna tela i ogranizacije. $\mathrm{Na}$ taj način unutrašnji međusobni konflikti ograničavaju mogućnosti koordiniranog državnog delovanja, snižavajući efikasnost i učinak državne politike. Imajući $\mathrm{u}$ vidu posebnu ulogu države u savremenoj ekonomiji, moguće je pretpostaviti da korupcija, birokratska rutina i protivurečnosti unutar aparata izvršne vlasti postaju ne manji problem od odsustva koordinacije, s kojom se obično povezuju mnogi tržišni nedostaci (Радыгин \& Энтов, 2012, 19).

\section{REGULATORNA FUNKCIJA DRŽAVE}

Ispravno određivanje prema državnim nedostacima može se, između ostalog, tumačiti i u kontekstu potrebnih uticaja u pravcu onemogućavanja nastanka tržišnih nedostataka, a samim tim i potonjih "otkaza" države $u$ nastojanjima da posledice tih nedostataka otkloni ili umanji. Kako su tržišni nedostaci, prema institucionalnim shvatanjima, posledica neefikasnog institucionalnog uređenja, to je potrebno da se država aktivira na planu donošenja i primene zakona u oblasti zaštite svojine, sprovođenja ugovora i garantovanja prava investitora. Ispostavlja se, dakle, da što je tržište manje savršeno to je uloga države i njenih institucija veća, pri čemu je bitno da državne institucije budu efikasne $u$ ispunjavanju glavnih ciljeva tržišne ekonomije (Leković, 2012, 70).

Pomenuti pristup ne zastupa aktivnu intervenciju države u kejnzijanskom i marksističkom smislu, sa namerom da država preuzme neke ingerencije tržišta. Ne polazi se od tržišta i države kao antipoda, već od paradoksalne pretpostavke da je za normalno funkcionisanje i zaštitu instituta privatne svojine i tržišta potreban mehanizam koji se zasniva na principima centralizovane i kolektivne svojine. Ovakvo poimanje odnosa između tržišta i države nije strano ni F. A. Hajek-u, kada tvrdi da "u meri u kojoj želimo da se koristimo uslugama tržišnih sila - a to, nesumnjivo moramo činiti ako želimo da očuvamo svoj životni standard - racionalna ekonomska politika se mora ograničiti na stvaranje uslova u kojima će tržište što bolje funkcionisati" (Hajek, 2001, 137). Ispostavlja se, dakle, da je najbolje profilisati komplementaran odnos tržišta i države, gde je poželjno intenziviranje državnih aktivnosti na polju uspostavljanja institucionalnog okvira, kao i značajno reduciranje direktnog, personalnog mešanja u tokove privređivanja. Posmatrano sa stanovišta psihološke nauke, reč je o fenomenu samoidentifikacije države kao regulatora, koji je, po svemu sudeći, u mnogim zemljama poprimio karakter hroničnog problema (Радыгин \& Энтов, 2012, 20). Tako nepovoljan scenario u značajnoj meri je povezan sa neadekvatnošću stabilizirajućih mehanizama i političkih instituta kojima bi se obezbedila ravnoteža između ciljeva države i ciljeva njenih agenata. Ono što je još problematičnije $\mathrm{u}$ tom smislu jeste to što se od države očekuje da napusti poziciju generalnog menadžera i redistributera $\mathrm{u}$ privredi, $\mathrm{i}$ prevashodno postane kreator instituta tržišne privrede i čuvar "pravila igre" (Sekulović, 2004, 114).

\section{RELEVANTNOST EMPIRIJSKIH ISTRAŽIVANJA DRŽAVNIH NEUSPEHA}

Među ekonomistima je široko rasprostranjeno mišljenje da su državni neuspesi bukvalno srasli sa organizacijom države i njenim ustrojstvom, i da su, kao takvi, neraskidivi, integralni deo funkcionisanja državnog poretka. Utisak je da i najširi slojevi stanovništa imaju stav o tome da su troškovi državne intervencije, po pravilu, nerealno visoki, i da tržišne neuspehe države ne uklanjaju uspešno i besplatno. Iako adekvatnost poimanja, prosuđivanja i zaključivanja građana o neefikasnom delovanju države ne treba nimalo osporavati i potcenjivati, predstavnici društvenih nauka su se potrudili da svojim empirijskim istraživanjima potkrepe tezu o 
postojanju državnih neuspeha. U tom smislu, poželjno je izdvojiti doprinos nekoliko teorijskih usmerenja, od kojih su neka uticajna među političkim naukama, dok su druga bliža ekonomskoj nauci. Tako se, na primer, pozitivistička škola iz Ročestera, čiji je utemeljivač V. Rajker, bavila istraživanjem izbora, stranačkih strategija, stvaranja koalicija, birokratskog ponašanja i tome slično (Rowley, 2008, 3-29). Značajan doprinos empirijskoj verifikaciji vezanoj za postojanje trgovanja na političkom tržištu vezuje se za G. J. Stigler-a (Stigler, 1971, 3-21), predstavnika tzv. čikaške škole. Unutar virdžinijske škole nastao je čitav niz studija protiv državne intervencije $\mathrm{u}$ privredi. Predvođeni J. Buchanan-om i G. Tullock-om, oni iznose činjenice koje ukazuju na odsustvo altruističkih motiva kod učesnika na političkom tržištu, misleći na izvršnu vlast, birokratiju, interesne grupe, zakonodavna tela, sudstvo i tome slično. U svojim kritikama "političkih tržišta" i neuspeha političkog delovanja, upozoravaju na problem trgovine glasovima. Teško je ignorisati činjenice o tome kako pojedinci mogu glasati protiv svojih preferencija, odnosno, za ono sa čime se ne slažu, ukoliko za uzvrat neko podrži njihov predlog (Buchanan \& Tullock, 1962, 43-46).

Budući da je traganje za rentom jedan od fundamentalnih koncepata kojim se ukazuje na državne nedostatke, indikativna su empirijska istraživanja koja pokazuju da traganje za rentom predstavlja karakteristiku svakog političkog sistema (Hindmoor, 2006, 161). Gotovo je nemoguće pronaći društva u kojima, na ovaj ili onaj način, nije prisutno traganje za rentom. Prema R. Posner-ovom istraživanju, tokom 1970-ih godina troškovi traganja za rentom u SAD iznosili su 3\% tadašnjeg američkog nacionalnog dohotka. Logično je pretpostaviti da su ovi troškovi viši u zemljama u kojima je korupcija raširenija, i u načelu odnose između 5\% i 40\% nacionalnog dohotka (Posner, 1975, 807-827).

Postojanje državnih neuspeha, između ostalog, može se dovesti u vezu i sa problemom kolektivnog delovanja. M. Olson-ova ideja po kojoj svako kolektivno delovanje sa sobom povlači problem "slobodnog korisnika", u praksi je praćeno brojnim poteškoćama povezanim sa motivisanjem članova društvenih grupa na aktivnije učešće u pravcu ostvarenja ciljeva tih grupa. Upravo to je, prema M. Olson-ovim istraživanjima, karakteristika procesa obezbeđenja javnih dobara i delovanja radničkih sindikata (Olson, 1965, 12, 66).

\section{ZAKLJUČAK}

$\mathrm{Na}$ osnovu razmatranja koncepcija i modela koji opisuju državne neuspehe, mišljenja eminentnih ekonomista, ponuđenih empirijskih podataka, kao i logičkih zaključaka i obrazloženja, može se reći da je potvrđena hipoteza po kojoj aktivnosti države usmerene na korekciju tržišnih neuspeha često mogu prouzrokovati lošije stanje $\mathrm{u}$ odnosu na ono koje bi bilo u slučaju odsustva tih istih aktivnosti. Pri tom je ukazano na to da nije poželjno biti isključiv $\mathrm{u}$ pretpostavci po kojoj svako prisustvo države $\mathrm{u}$ ekonomiji, po pravilu, donosi samo štetu, niti da su svi politički akteri i državni činovnici skloni korupciji i rentijerskom ponašanju. Istraživanja državnih neuspeha ne treba svesti samo na popularno otkrivanje odnosa, odnosno, suprotstavljanje države i tržišta. Apsolutno je neprihvatljivo bilo kakvo uprošćavanje istraživanja na pozicijama tržišnog ili, naprotiv, državnog fundamentalizma.

Dugo vremena ekonomska teorija nije posvećivala dovoljno pažnje i prostora proučavanju ekonomskih tokova koji su posledica uzajamnog dejstva različitih socijalnih i političkih faktora. U kontekstu međusobnih veza i odnosa, politički proces neretko je ovladavao sopstvenom logikom, koja u mnogim slučajevima nije odgovarala stavovima optimizirajućih ekonomskih mehanizama. Učesnici političkog života i državni službenici često se nisu rukovodili kriterijumima i motivima ostvarivanja ekonomske efikasnosti. U vezi s tim, razmere privredne neefikasnosti i rasipništva bivale su višestruko pojačavane neadekvadnim delovanjem političkih struktura, nesavršenom koordinacijom rada višestrukih nivoa vlasti, nedovoljnom transparentnošću prilikom donošenja odluka u okvirima neusklađenog i neretko rentijerski motivisanog ponašanja birokratije.

Pomenute konstatacije i stavovi mogu poslužiti kao dobra osnova za analizu uzajamnog dejstva države i tržišta u sistemu odnosa privređivanja. Zajedno s tim stvaraju se uslovi za ispravno poimanje državnih nedostataka. Pri tom je posebno važno to što je, uporedo 
sa konstatacijom standardne ekonomske teorije o postojanju tržišnih i državnih nedostataka, neophodno potpunije teorijsko obrazloženje uzajamnog delovanja centralizovanih i decentralizovanih sistema regulacije. $\mathrm{U}$ tom smislu, potrebno je podržati interdisciplinarni pristup u procesu istraživanja prednosti i nedostataka pomenutih mehanizama, koji istovremeno postulira na shvatanjima ekonomske, političke i sociološke nauke.

Razmere državnih nedostataka zavise kako od obima državne aktivnosti, tako i od forme političke ogranizacije države, posebno političke kulture, stepena demokratizacije društva i strukture delovanja društvenih instituta. Posmatrano sa aspekta Republike Srbije, pouzdano se može tvrditi da je ona, kao zemlja u tranziciji, dodatno izložena brojnim problemima vezanim za aktiviranje i sprovođenje državne intervencije. Republika Srbija se danas suočava sa brojnim uzrocima državnih neuspeha, što je praćeno negativnim posledicama po efikasnost privrede, životni standard stanovništva, funkcionisanje države itd. Na delu je svakodnevno potvrđivanje neefikasnosti mehanizma kolektivnog odlučivanja, što je praćeno neodgovarajućom koordinacijom između pojedinih nivoa i delova državne administracije. Kontrola donetih mera otežana je, pošto je njihovo sprovođenje, po pravilu, prosleđeno državnim službama i organima nižeg hijerarhijskog nivoa. Skupština Republike Srbije retko dobija pouzdane povratne informacije o sprovođenju donetih odluka, zbog čega ne može da pravovremeno reaguje i prilagođava svoje odluke. Ekonomska neefikasnost i brojni problemi sa kojima se susreće veliki broj javnih preduzeća potvrđuju tezu o nepostojanju ugrađenih mehanizama koji bi osigurali Pareto-efikasnu alokaciju resursa.

RS je, svakako, reprezentativni primer kada je $\mathrm{u}$ pitanju nepostojanje neposrednih pokazatelja uspešnosti rada državnih organa i javnih službi. Obično se pretpostavlja da je vrednost javnih dobara i usluga jednaka državnim rashodima potrebnim za funkcionisanje državnih preduzeća koja obezbeđuju ta javna dobra. Aktuelni problemi vezani za budžetski deficit i plan najavljenih ušteda nedvosmisleno potvrđuju da $u$ javnom sektoru ne postoji potrebna veza između državnih troškova i prihoda, zbog čega se povećava prostor za neadekvatnu alokaciju resursa i pojavu nepotrebnih troškova.
Nepostojanje neposrednih mera uspešnosti državnih činovnika doprinosi nekvalitetnom i nepravovremenom obavljanju dužnosti, stvarajući plodno tlo za širenje korupcije. Svedoci smo brojnih, gotovo svakodnevnih afera zloupotrebe službenog položaja vezanih za poslovanje javnih preduzeća i državnih organa u Srbiji. Gorka spoznaja činjenica o nesavesnom ponašanju nemalog broja rukovodilaca javnih preduzeća i državnih činovnika svakako doprinosi afirmaciji teorije javnog izbora i njene temeljne pretpostavke o tome da se učesnici u političkoj sferi društvenog života ponašaju tako što donose odluke sledeći sopstvene interese.

Analiza državnih neuspeha, na teorijskometodološkom nivou i iz ugla funkcionisanja domaće privrede, nosiocima ekonomske politike treba da posluži kao relevantan izvor informacija za vođenje ekonomske politike i kreiranje instituta tržišne privrede. Ukoliko bi nosioci ekonomske politike $\mathrm{u}$ Srbiji na pravi način pronikli u fenomenologiju državnih nedostataka, stvorili bi se uslovi za donošenje adekvatnih mera na osnovu kojih bi se izračunala efikasnost javnih preduzeća, efikasnost konkretnih državnih aktivnosti i, u skladu s tim, definisao poželjni kvalitet javnih dobara. Da bi se to ostvarilo, potrebno je uvažiti i adekvatno vrednovati socijalnu dimenziju realnih životnih prilika, i zajedno s tim afirmisati politiku efikasne države, a sve to nasuprot ideologiji sveprisutne države koja uvek interveniše povodom tržišnih nedostataka i, političarima jako primamljive, koncepcije „države radi države“.

\section{REFERENCE}

Acemogly, D. (2003). Whay Not a Political Coase Theorem? Journal of Comparative Economics, 31, 620-659.

Alchian, A., \& Demsetz, H. (1973). The Property Right Paradigm. The Journal of Economic History, 33(1), 16-27.

Alesina, A., \& Tabellini, G. (2007). Bureaucrats or Politicans? American Economic Review, 97, 169-179.

Banerjee, A. (1997). A Theory of Misgovernance. Quarterly Journal of Economics, 112(4), 1289-1332. 
Bozeman, B. (2002). Public - Value Failure: When Efficient Markets May nor Do. Public Administration Review, 62(2), 145161.

Buchanan, J., \& Tullock, G. (1962). The Calculus of Consent: Logical Foundations of Constitutional Democracy. USA: University of Michigan Press.

Drazen, A. (2000). Political Economy in Macroeconomics. New Jersey: Princeton University Press.

Geanokoplos, J. (2005). Three brief proofs of Arrow's Impossibility Theorem. Economic Theory, 26, 211-215.

Gunning, P. (2002). Understanding Democracy: An Introduction to Public Choice. http://www.fortunecity.com/meltingpot/ barclay/212/votehtm/cont.htm.

Hajek, F. A. (2000). Ekonomija, nauka i politika. Ekonomski anali, 44(147-148), 126-155.

Хайек Ф. (2006). Право, законодательство и свобода. Москва, Россиа: ИРИСЭН, Мысль.

Hindmoor, A. (2006). Rational Choice. UK: Palgrave Macmillan.

Kitanović, D., Golubović, N., Petrović, D., i Džunić, M. (2011). Savremena politička ekonomija. Niš, Srbija: Ekonomski fakultet.

Коуз, Р. (1993). Фирма, рынок и право. Москва, Россиа: Дело.

Krueger, A. (1990). Government Failures in Development. The Journal of Economic Perspectives, 4(3), 9-23.

Leković, V. (2012). Poverenje kao institucionalni faktor ekonomske uspešnosti. Ekonomski horizonti, 14(2), 63-75. doi: 10.5937/ekonhor1202063L

Mankju, G. N. (2004). Principi ekonomije. Beograd, Srbija: Ekonomski fakultet

Myerson R. (1993). Effectiveness of Electoral Systems for Reducing Government Cooruption: A Game Theoretic Analysis. Games and Economic Behavior, 5, 118-132.

Niskanen, W. (1971). Bureaucracy and Representative Government. Chicago: Aldine-Atherton.

Nordhaus, W. D. (1975). The Political Business Cycle. Review of Economic Studies, 42, 169-190.

Olson, M. (1965). The Logic of Colective Action. Harvard University Press.
Petak, Z. (2001). Javna dobra i političko odlučivanje. Zagreb, Hrvatska: Fakultet političkih znanosti.

Pigou, A. (1932). The Economics of Welfare. National Dividend. London, UK: MacMillan.

Posner, R. (1975). The Social Costs of Monopoly and Regulation. Journal of Political Economy, 83(4), 807-827.

Praščević, A. (1999). Teorija političkih ciklusa umakroekonomiji. Ekonomski anali, 43(142), 35-53.

Prokopijević, M. (2000). Konstitucionalna ekonomija. Beograd, Srbija: E-Press.

Радыгин, А., \& Энтов, Р. (2012). Провалы государства: теория и политика. Вопросы экономики, 12, 4-30.

Robbins, L. (1962). The Nature and Significance of Economic Science. London, UK: MacMillan.

Rowley, C. K. (2008). Public Choice and Constitutional Political Economy. In C. K. Rowley \& F. Schneider (Eds.), Readings in Public Choice and Constitutional Political Economy (pp 3-30). Springer Science + Bussines Media LLC.

Sekulović, M. (2004). Ogledi o tranziciji. Niš, Srbija: Ekonomski fakultet.

Sen, A. (2004). Racionalnost i društveni izbor. Ekonomski anali, $44(160), 221-253$.

Stigler, G. J. (1971). The Theory of Economic Regulation. The Bell Journal of Economics and Management Science, 2(1), 3-21.

Tideman, T. (1997). Voting and the Revelation of Preferences for Public Activities/Perspectives on Public Choice. Cambridge: Cambridge University Press.

Tullock G. (1978). Welfare Effects of Sales Maximization. Economic Inquiry, 16, 113-118.

Tullock G., Seldon. A., \& Brady, G. (2002). Government Failure: A Primer in Public Choice. Washington, DC: Cato Institute.

Vining, A., \& Weimer, D. (1990). Government Supply and Government Production Funciton: A Framework Based on Contestability. Journal of Public Policy, 10, 1-22.

Weber, M. (1958; 1921). From Max Weber. Oxford, UK: Oxford University Press.

Wolf, C. (1979). A Theory of Nonmarket Failure. Journal of Law and Economics, 22(1), 107-139. 
Dragan Petrović je vanredni profesor na Ekonomskom fakultetu Univerziteta u Nišu, na nastavnom predmetu Politička ekonomija. Doktorirao je iz oblasti institucionalne ekonomije, na Ekonomskom fakultetu Univerziteta u Nišu. Osnovne oblasti naučnog istraživanja su relevantna pitanja institucionalne ekonomije, ekonomskog sistema i ekonomske politike.

\title{
THE KEY THEORETICAL AND PRACTICAL ASPECTS OF THE STATE FAILURES IN THE CONTEMPORARY ECONOMY
}

\author{
Dragan Petrovic \\ Faculty of Economics, University of Nis, Nis, Serbia
}

The subject of this paper is to analyze the evolution of approaches to the problem of the "state failure". This phenomenon arose from the concept of "market failures", which in economic theory can be seen in the context of searching for new strategies of the political and economic mechanisms of resource allocation. In this regard, special attention will be focused on the identification of the components of the institutional impact on the efficiency of economic processes, which first involves a general review of the role of the state in the economy. A multidisciplinary approach to the study of such a complex issue requires, among other things, that all information problems in the analysis of the economic functions of the public sector be taken into consideration, that the possibilities of financing public policy measures be appreciated, that the role and influence of the political process and the rent-oriented behavior of public officials be adequately evaluated, and ultimately that an attempt to identify the negative external effects caused by the absence, but also by the presence, of the state coordination in the economy be made.

Keywords: state failures, the theory of public choice, the mechanism of collective decision making, informational problems

JEL Classification: D72, D73, D74, H41 